ORIGINAL ARTICLE

\title{
Pasting properties of raw and extruded cowpea cotyledons flours
}

\section{Propriedade da pasta de farinha de cotilédones de feijão-caupi crua e extrusada}

\author{
Jorge Minoru Hashimoto $^{1 *}$ (D), Marcio Schmiele ${ }^{2}$ (D), Elizabeth Harumi Nabeshima ${ }^{3}$ \\ ${ }^{1}$ Empresa Brasileira de Pesquisa Agropecuária (EMBRAPA), Teresina/PI - Brasil \\ 2 Universidade Federal dos Vales do Jequitinhonha e Mucuri (UFVJM), Instituto de Ciência e Tecnologia - \\ Engenharia de Alimentos, Diamantina/MG - Brasil \\ ${ }^{3}$ Instituto de Tecnologia de Alimentos (ITAL), Campinas/SP - Brasil
}

${ }^{*}$ Corresponding Author: Jorge Minoru Hashimoto, Brazilian Agricultural Research Corporation (EMBRAPA), Av. Duque de Caxias, 5650, CEP: 64008-780, Bairro Buenos Aires, Teresina/PI - Brasil. e-mail: jorge.hashimoto@embrapa.br

Cite as: Hashimoto, J. M., Schmiele, M., \& Nabeshima, E. H. (2020). Pasting properties of raw and extruded cowpea cotyledons flours. Brazilian Journal of Food Technology, 23, e2019303. https://doi.org/10.1590/19816723.30319

\begin{abstract}
There is little research on the viscosity profile analysis of cowpea cotyledon flour (CCF). Due to the new ways of using pulses grains in the diet, it is important to evaluate the viscoamylographic behavior of raw and processed CCF. The CCF was obtained from the cultivars BRS Guariba and BRS Novaera and evaluated in the Rapid Visco Analyzer (RVA). For raw CCF it was used the "Standard 1" program. The extruded CCF was obtained from the cultivar BRS Guariba, which was processed following a central rotational composite design, combining thermoplastic extrusion temperatures $\left(124 ; 130 ; 145 ; 160 ; 166^{\circ} \mathrm{C}\right)$ and conditioning moisture $(16.2 \% ; 17 \% ; 19 \% ; 21 \%, 21.8 \%)$. The obtained extrusions were ground $(\varnothing>0.5 \mathrm{~mm})$ and evaluated in the RVA using the program "Extrusion 2". The raw CCF from BRS Guariba presented higher protein, lipid and mineral content and lower carbohydrate content than BRS Novaera. The raw CCF from BRS Guariba showed lower values of pasting temperature $\left(79.35^{\circ} \mathrm{C}\right)$, viscosity breakdown $(103.00 \mathrm{CP})$ and seatback $(1447.33 \mathrm{CP})$ compared to raw CCF from BRS Novaera. The extrusion process drastically changed all viscosity parameters, increasing the initial viscosity value and decreasing the value of other parameters. The extruded CCF had different pasting properties. CCF extruded at $166^{\circ} \mathrm{C}$ and $19 \%$ moisture resulted in flours with higher initial viscosity and lower retrogradation values, which can be used as a thickener in food products, in addition to increase nutritional value.
\end{abstract}

Keywords: Vigna unguiculata; Extrusion; Viscosity; Instant flour; Rapid Visco Analyzer; Retrogradation.

\section{Resumo}

Há poucas pesquisas sobre a análise do perfil de viscosidade de farinhas de cotilédone de feijão-caupi (FCFC). Devido às novas formas de utilização dos grãos de pulses na dieta, torna-se importante avaliar o comportamento viscoamilográfico de FCFC cruas e processadas. As FCFC foram obtidas das cultivares BRS Guariba e BRS Novaera e avaliadas no Rapid Visco Analyzer (RVA). Para a FCFC crua foi utilizado o programa "Standard 1". As FCFC processadas foram obtidas da cultivar BRS Guariba, que foi extrusada seguindo um delineamento composto central 
rotacional, combinando temperaturas de extrusão termoplásticas $\left(124 ; 130 ; 145 ; 160 ; 166{ }^{\circ} \mathrm{C}\right)$ e umidade de condicionamento (16,2\%; 17\%; 19\%; $21 \% ; 21,8 \%)$. Os extrusados obtidos foram moídos $(\varnothing>0,5 \mathrm{~mm})$ e avaliados no RVA utilizando o programa "Extrusion 2". A FCFC crua da BRS Guariba apresentou maior teor de proteínas, lipídios e minerais e menor teor de carboidratos que a BRS Novaera. A FCFC crua da BRS Guariba apresentou valores inferiores de temperatura de pasta $\left(79,35^{\circ} \mathrm{C}\right)$, quebra da viscosidade $(103,00 \mathrm{cP})$ e retrogradação $(1447,33 \mathrm{cP}) \mathrm{em}$ comparação à FCFC crua da BRS Novaera. O processo de extrusão alterou drasticamente todos os parâmetros de viscosidade, aumentando o valor inicial de viscosidade e diminuindo o valor dos demais parâmetros. As FCFC extrusadas apresentaram diferentes propriedades de pasta. A FCFC extrusada a $166^{\circ} \mathrm{C}$ e $19 \%$ de umidade resultou em farinhas com maior viscosidade inicial e menores valores de retrogradação, que podem ser utilizadas como espessante em produtos alimentícios, além de aumentar o valor nutricional.

Palavras-chave: Vigna unguiculata; Extrusão; Viscosidade; Farinha instantânea; Rapid Visco Analyzer; Retrogradação.

\section{Introduction}

Common bean (Phaseolus vulgaris) and cowpea (Vigna unguiculata) are the two main pulses cultivated on a large scale in Brazil, with the production of 2,624 and 647 thousand tons in 2017, respectively. The Northeast region accounted for $63.4 \%$ of cowpea production (Empresa Brasileira de Pesquisa Agropecuária, 2019), because this species is rustic, with wide adaptability, tolerating high temperatures and water deficits in this region. Brazil was the third largest cowpea producer in 2017, behind Nigeria (3.4 million tons), and Niger (2.0 million tons) (Food and Agriculture Organization of the United Nations, 2019).

The cowpea segment has been innovating with the introduction of the raw decorticated grain flour, a product of higher added value, greater storage stability and convenience (Gomes et al., 2012), which has been mainly used for the preparation of "acarajé" pasta and incorporated in bakery product formulations for nutritional enrichment. Another segment with potential for growth is ready-to-eat or fast-preparing products based on pulses, associating attractive consumer characteristics such as convenience, practicality, healthiness and nutritional quality (Boye et al., 2010). Thermoplastic extrusion technology has been used for the development of expanded products and instant flours because of its high versatility and efficiency (Brennan et al., 2013), low cost, high productivity, short reaction time and no effluent generation. The process promotes macromolecular interactions and degradations, the intensity depends on the conditions used, modifying the mechanical, thermal and texture properties (Ortiz et al., 2008), which can be detected through the property of starch paste or flour. This feature is important in helping to predict the functionality or behavior of these raw materials (Fox et al., 2014) during the processing and storage of food products, better targeting their use.

The rheological properties of raw flour have been used to detect subtle differences between genotypes within a plant species (Kesarwari et al., 2016) and changes in the profile of these properties caused by processing (Ye et al., 2018; Kesarwari et al., 2016). The objective of this research was to verify the raw flour paste properties of two cowpea cultivars and the effect of the extrusion process on the temperature and moisture content of the flour conditioning on these characteristics.

\section{Material and methods}

\subsection{Raw cotyledons flour}

Cowpea grains of cultivar BRS Guariba and BRS Novaera produced in Sorriso, MT, Brazil, were decorticated (Comercial MaqLand Ltda., Model DSF 2000, Londrina, PR, Brazil) and the cotyledons ground in a knife mill (Renard Indústria e Comércio Ltda., Model MFC-180-75-01 01 No. 5753, São Paulo, SP, 
Brazil) with a $3 \mathrm{~mm}$ mesh sieve coupled to the outlet and transformed into CCF in the roller mill (Brabender OHG, Senior Quadrumat Model, Duisburg, North Rhine-Westphalia, Germany).

\subsection{Chemical analysis}

The chemical composition of flour was determined according to the method of the Association of Official Analytical Chemists (2012). Carbohydrate content was calculated by difference.

\subsection{Extruded flour}

BRS Guariba CCF was processed in the co-rotational intertwined twin-screw extruder (Werner \& Pfleiderer Co., model ZSK 30, Ramsey, NJ, USA). The experimental design was the Central Rotational Compound (Barros Neto et al. 2010) to evaluate the effect of the two independent variables: process temperature (x1) and flour moisture (x2), in five levels $(-\alpha ;-1 ; 0 ; 1 ; \alpha$, where $\alpha=\sqrt{ } 2)$, as shown in Table 1 .

The following temperature settings were used on the extruder: $1^{\text {st }}$ zone at $75^{\circ} \mathrm{C}, 2^{\text {nd }}$ zone at $100{ }^{\circ} \mathrm{C}, 3^{\text {rd }}$ zone always $10^{\circ} \mathrm{C}$ below the $4^{\text {th }}$ zone setting, and the temperature of this zone was adjusted according to the experimental design (Table 1). A die with two-hole of $2.8 \mathrm{~mm}$ diameter, a feed rate of $13 \mathrm{~kg} / \mathrm{h}$, a screw rotation speed of $260 \mathrm{rpm}$ and a rotary knife at the die outlet at $26 \mathrm{rpm}$. The extrudates were collected 5 minutes after reaching the programmed temperatures in the respective zones and then transferred to a drying drum (Inbramaq, model 2068, Ribeirão Preto, SP, Brazil), adjusted to $95{ }^{\circ} \mathrm{C}$ for 1 minute. Drying was later complemented in a forced air circulation oven at $80 \pm 0.2^{\circ} \mathrm{C}$ (Tecnal, model TE-394/2, Piracicaba, SP, Brazil) until reaching moisture content between 6 and $8 \%$. Part of the extrudates was ground in a blender (OXY, model OBL 10/2, Santana de Parnaíba, SP, Brazil) at $35.000 \mathrm{rpm}$ for three min., and sieved in $0.5 \mathrm{~mm}$ mesh to determine the viscoamylographic parameters.

Table 1. Levels expressed in coded and real values of experimental conditions of experimental design 22 of the cowpea cotyledon flour (CCF) extrusion process.

\begin{tabular}{|c|c|c|c|c|}
\hline \multirow{2}{*}{ Treatments } & \multicolumn{2}{|c|}{ Encoded values } & \multicolumn{2}{|c|}{ Real values } \\
\hline & $\mathbf{x}_{1}$ & $\mathbf{x}_{2}$ & $\begin{array}{c}\text { Temperature in the } \\
4^{\text {th }} \text { zone }^{1}\left({ }^{\circ} \mathrm{C}\right)\end{array}$ & Moisture (\%) \\
\hline 1 & -1 & -1 & 130 & 17 \\
\hline 2 & 1 & -1 & 160 & 17 \\
\hline 3 & -1 & 1 & 130 & 21 \\
\hline 4 & 1 & 1 & 160 & 21 \\
\hline 5 & $-\alpha$ & 0 & 124 & 19 \\
\hline 6 & $\alpha$ & 0 & 166 & 19 \\
\hline 7 & 0 & $-\alpha$ & 145 & 16.2 \\
\hline 8 & 0 & $\alpha$ & 145 & 21.8 \\
\hline 9 & 0 & 0 & 145 & 19 \\
\hline 10 & 0 & 0 & 145 & 19 \\
\hline 11 & 0 & 0 & 145 & 19 \\
\hline 12 & 0 & 0 & 145 & 19 \\
\hline
\end{tabular}

${ }^{1}$ The temperatures of the $1^{\text {st }}$ and $2^{\text {nd }}$ zones were $75^{\circ} \mathrm{C}$ and $100{ }^{\circ} \mathrm{C}$, respectively, and the $3^{\text {rd }}$ zone was always $10^{\circ} \mathrm{C}$ below the $4^{\text {th }}$ zone. 


\subsection{Raw and extrude CCF viscosity profile}

The viscoamylographic behavior of raw and extruded CCF was determined according to ICC method 162 (International Association for Cereal Science and Technology, 1996) using an RVA viscometer (Rapid Visco Analyzer), model RVA 4500 (Warriewood, Australia), 4.0 and $5.0 \mathrm{~g}$ of sample (with moisture correction to $14 \%$ ), respectively, and $25 \mathrm{~mL}$ of distilled water for each sample. The profile used was Standard 1 for raw CCF and Extrusion 2 for extruded CCF (Table 2). For comparison purposes, raw CCF from BRS Guariba was also subjected to an analytical profile and the curves analyzed by TCW software 3.15.1.255. The parameters evaluated for the raw CCF were: pasting temperature (PT), peak viscosity (PV), trough (TR), breakdown (BD), final viscosity (FV) and setback (SB). For the extruded CCF were evaluated: initial cold viscosity (IV), peak viscosity (PV), trough (TR), breakdown (BD), final viscosity (FV) and setback (SB). The analyzes were performed in triplicate and the results expressed in ${ }^{\circ} \mathrm{C}$ for pasting temperature and in $\mathrm{cP}$ for the other parameters.

Table 2. Thermocline for Windows RVA "Standard 1" and "Extrusion 2" programming used for flour paste analysis.

\begin{tabular}{ccccccc}
\hline & Standard 1 & & & \multicolumn{2}{c}{ Extrusion 2 } \\
\cline { 1 - 3 } Time & Parameter & Value & & Time & Parameter & Value \\
\hline $00: 00: 00$ & Temperature & $50^{\circ} \mathrm{C}$ & & $00: 00: 00$ & Temperature & $25^{\circ} \mathrm{C}$ \\
\hline $00: 00: 00$ & Rotation speed & $960 \mathrm{rpm}$ & $00: 00: 00$ & Rotation speed & $960 \mathrm{rpm}$ \\
\hline $00: 00: 10$ & Rotation speed & $160 \mathrm{rpm}$ & $00: 00: 10$ & Rotation speed & $160 \mathrm{rpm}$ \\
\hline $00: 01: 00$ & Temperature & $50^{\circ} \mathrm{C}$ & $00: 02: 00$ & & Temperature & $25^{\circ} \mathrm{C}$ \\
\hline $00: 04: 42$ & Temperature & $95^{\circ} \mathrm{C}$ & $00: 07: 00$ & & Temperature & $90^{\circ} \mathrm{C}$ \\
\hline $00: 07: 12$ & Temperature & $95^{\circ} \mathrm{C}$ & $00: 10: 00$ & & Temperature & $90^{\circ} \mathrm{C}$ \\
\hline $00: 11: 00$ & Temperature & $50^{\circ} \mathrm{C}$ & $00: 15: 00$ & Temperature & $25^{\circ} \mathrm{C}$ \\
\hline
\end{tabular}

\subsection{Statistical analysis}

Raw flours were compared by the Scott-Knott clustering test at 5\% probability level. The extruded flour data were subjected to multiple regression analysis using the Statistical program (StatSoft, Version 10). The second-order polynomial model was selected to predict the region of the optimal point of the responses: $y=\beta_{0}+\beta_{1} x_{1}+\beta_{2} x_{2}+\beta_{11} x_{1}^{2}+\beta_{22} x_{2}^{2}+\beta_{12} x_{1} x_{2}$

Where $y$ represents the response variable, $\beta_{0}$ the intercept, while $\beta_{1}$ and $\beta_{2}$ the linear terms, $\beta_{11}$ and $\beta_{22}$ the quadratic terms, and $\beta_{12}$ the interaction term, $\mathrm{x}_{1}$ and $\mathrm{x}_{2}$ are the independent variables, coded for temperature and moisture, respectively. When the regression model obtained for a given independent variable was not significant $(p<0.05)$, the Scott-Knott grouping test at 5\% probability level was applied.

\section{Results and discussion}

\subsection{Chemical composition}

Raw CCF chemical compositions are presented in Table 3 . The protein and mineral contents of the CCF of BRS Guariba were higher $(p<0.05)$ than BRS Novaera, while the carbohydrate content was lower $(p<0.05)$ in BRS Guariba, and for lipid content no significant differences were observed $(p<0.05)$. The chemical composition values presented in the two CCF are close to those of cowpea whole grains presented in the Brazilian Table of Food Composition (Núcleo de Estudos e Pesquisas em Alimentação, 2011). 
Table 3. Chemical composition of cowpea cotyledon flour (\%, d.b.).

\begin{tabular}{ccccc}
\hline Cultivar & Protein & Lipids & Carbohydrates & Minerals \\
\hline BRS Guariba & $23.98 \pm 0.28 \mathrm{a}$ & $1.89 \pm 0.10 \mathrm{a}$ & $69.92 \pm 0.16 \mathrm{~b}$ & $4.22 \pm 0.03 \mathrm{a}$ \\
\hline BRS Novaera & $21.08 \pm 0.36 \mathrm{~b}$ & $1.73 \pm 0.07 \mathrm{a}$ & $74.15 \pm 0.38 \mathrm{a}$ & $3.04 \pm 0.05 \mathrm{~b}$ \\
\hline
\end{tabular}

Means followed by the same letter in the column do not differ statistically from each other by the Scott-Knott test at $5 \%$ probability.

\subsection{Raw CCF paste property}

Characterization of flour paste properties has been used as a tool to identify differences between cultivars (Adegunwa et al., 2012) or progeny selection (Arcaute et al., 2017). The evaluation of paste property indicates the most appropriate application of flour (Adebowale et al., 2005). This property depends on the molecular structure of starch and the components contained in flour (Huang et al., 2007).

$\mathrm{PT}$ is the temperature at which the first increase in $2 \mathrm{RVU}$ units, corresponding to $24 \mathrm{cP}$, within 20 seconds during the warm-up period, indicates the minimum temperature for the starch cooking. This value is slightly beyond the gelatinization point (Olkku \& Rha, 1978). The PT of BRS Guariba raw CCF was $79.35{ }^{\circ} \mathrm{C}$, significantly lower $(p<0.05)$ than that of BRS Novaera $\left(82.08{ }^{\circ} \mathrm{C}\right)$, indicating that the starch granules contained in the latter CCF are more resistant to gelatinization and the lower PT value may be related to higher amylose content. Cowpea has been reported to have large amounts of long-chain amylopectin, which provides a strong association of these structures forming crystalline regions, resulting in higher gelatinization temperature, higher swelling volume, and higher viscosity peak values at $95{ }^{\circ} \mathrm{C}$ (Huang et al., 2007). The values of PT obtained were similar to those of other CCF analyzes (Adebooye \& Singh, 2008; Henshaw et al., 1996; Malomo et al., 2017), and in cowpea starch (Huang et al., 2007). The values obtained were higher concerning chickpea starch $\left(70.9^{\circ} \mathrm{C}\right)$ and yellow pea $\left(70.5^{\circ} \mathrm{C}\right)$ (Huang et al. 2007), but lower than that of pigeon pea $\left(94^{\circ} \mathrm{C}\right.$ to $96^{\circ} \mathrm{C}$ ) (Adenekan et al., 2014). However, Adegunwa et al. (2012) obtained much lower $\mathrm{PT}$ values in $\mathrm{CCF}$, ranging from $61.88^{\circ} \mathrm{C}$ to $62.03{ }^{\circ} \mathrm{C}$. Comparatively, the main flours used in food have a lower PT value, for wheat flour, it has been found a value of $65.38^{\circ} \mathrm{C}$ (Baranzelli et al., 2016) and in whole corn flour of $69.63{ }^{\circ} \mathrm{C}$ and $78.48{ }^{\circ} \mathrm{C}$ (Camargo et al., 2014).

$\mathrm{PV}$ is defined as the maximum viscosity that occurs before the start of sample cooling (International Association for Cereal Science and Technology, 1996). This viscosity is achieved when most starch granules are fully hydrated which indicates the ability of water to bind to starch granules (Shimelis et al., 2006) and also often correlates with the quality of the final product (Ashogbon \& Akintayo, 2013). The maximum viscosity achieved by the two cultivars did not present significant differences $(p<0.05)$ (Table 3$)$. In studies using CCF, it has been obtained PV of 371.7 RVU or 4,460.4 cP (Malomo et al., 2017) and 340 RVU or 4,080 cP (Olapade et al., 2005), values higher than those observed in this research. Comparing 3 cowpea cultivars, PV values have been obtained from 101.42 to $114.74 \mathrm{RVU}(1,217.04$ to $1,376.88 \mathrm{cP})$ (Adegunwa et al., 2012).

TR is the lowest viscosity value recorded after the peak viscosity (International Association for Cereal Science and Technology, 1996). This value measures the ability of starch granules to resist breakage during cooking (Olkku \& Rha, 1978). This value is influenced by the extent of amylose leaching, amylose-lipid complex formation, friction between swollen starch granules, and competition between leached amylose and remaining free granules in water (Olkku \& Rha, 1978). The values obtained for TR demonstrate that BRS Guariba starch granules resisted better $(p<0.05)$ the breakage than BRS Novaera.

BD is an index of starch stability (Fernandez \& Berry, 1989). This value is calculated by the difference between the PV and the TR, that is, the difference between the viscosity provided by the gelatinized starch granules and after their partial or total rupture (Han \& Hamaker, 2001). This value measures the vulnerability of cooked starch to disintegration (Wani et al., 2012). The higher BD value, the lower the starch granule's ability to withstand heating and shear stress during cooking (Adebowale et al., 2005). BRS Novaera flour 
was more susceptible $(p<0.05)$ to disintegration during heating and shear, presenting a BD value 5 times higher than BRS Guariba. During disintegration, the swollen granule breaks and the amylose molecules are leached into solution (Zaidul et al., 2007).

SB is related to the reassociation, retrogradation, or reordering of starch molecules. With decreasing temperature, leached amylose and amylopectin molecules tend to reassociate. Low SB values in CCF indicate that it is less susceptible to retrogradation (aggregation of part of starches to form precipitated microcrystals). High SB values are associated with syneresis. The SB values of flour have been correlated with the texture of various products (Michiyo et al., 2004). BRS Novaera CCF SB was significantly higher $(p<0.05)$ than BRS Guariba CCF (Table 4), so it was less susceptible to retrogradation.

The FV is the viscosity at the end of the test (International Association for Cereal Science and Technology, 1996), also known as the viscosity of the paste in cooling. This value indicates the ability of flour to form a viscous paste or gel after cooking and cooling. The increase in FV value can be attributed to the aggregation of amylose molecules in cooling (Kaur et al., 2007). The difference in FV between cultivars may be associated with differences in amylose contents, those with high amylose starches re-associate faster than high amylopectin starches. This is because linear chains (amylose molecules) can orient parallel to each other so that mobility and union are more efficient (Shimelis et al., 2006). The CCF FV of BRS Guariba was higher $(p<0.05)$ than that of BRS Novaera (Table 4).

Table 4. Viscosity parameters of raw flour of cowpea cultivars.

\begin{tabular}{ccccccc}
\hline Cultivar & PT $\left({ }^{\circ} \mathbf{C}\right)$ & PV (cP) & TR (cP) & BD (cP) & FV (cP) & SB (cP) \\
\hline BRS Guariba & $79.35 \mathrm{~b}$ & $3408.33 \mathrm{a}$ & $3305.33 \mathrm{a}$ & $103.00 \mathrm{~b}$ & $4752.67 \mathrm{a}$ & $1447.33 \mathrm{~b}$ \\
\hline BRS Novaera & $82,07 \mathrm{a}$ & $3389.33 \mathrm{a}$ & $2853.33 \mathrm{~b}$ & $536.00 \mathrm{a}$ & $4486.33 \mathrm{~b}$ & $1633.00 \mathrm{a}$ \\
\hline
\end{tabular}

Means followed by the same letter in the column do not differ statistically from each other by the Scott-Knott test at $5 \%$ probability.

\subsection{Paste property of extruded flours}

BRS Guariba's raw CCF was submitted to thermoplastic extrusion, receiving during the processing thermal and mechanical energy of different intensities, according to the combination of the independent variables, which caused changes in the paste properties (Table 5). All Linear, quadratic effects and interactions of the quadratic model applied to the extruded CCF paste properties as a function of the extrusion process parameters moisture $(\mathrm{M})$ and temperature $(\mathrm{T})$ were calculated. The regression and determination coefficients are presented in Table 6 .

IV is the measured viscosity value of the suspension at $25{ }^{\circ} \mathrm{C}$, a very important parameter in the development and preparation of instant foods. This property indicates the ability of flour to absorb water at room temperature to turn into paste, gel, or viscous substance (Souza et al., 2011). Raw flours tend to have a near-zero IV value at $25^{\circ} \mathrm{C}$ due to the absence of gelatinized starch granules (Souza et al., 2011) and are high when the sample is previously gelatinized and decrease in severe processing conditions, due to starch depolymerization with cooking (Menegassi et al., 2007). The viscosity value for the raw flour of cultivar BRS Guariba was only $36.67 \mathrm{cP}$, much lower than extruded CCF, whose IV ranged from 292.33 to $458.33 \mathrm{cP}$. The coefficient of determination for IV was low $\left(\mathrm{r}^{2}=0.69\right)$ and the model was not significant (Table 6). By grouping test Scott-Knott formed 5 distinct groups $(p<0.05)$. Extruded CCF IV values were much higher than raw flour, which is a common characteristic of instant flour.

The viscosity behavior during cooking reflects the ability of starch to absorb water and swell (Sandhu et al., 2007). Extruded flours generally have lower viscosity values than raw counterparts due to loss of starch granule integrity (Ye et al., 2018). For all extruded flours the value of PV was higher than that of IV (Table 5), PV values ranged from $353.67 \mathrm{cP}$ to $616.67 \mathrm{cP}$, forming 4 distinct clusters by the Scott-Knott test $(p<0.05)$. This implies that there are remaining whole or partially intact starch granules that have resisted 
heating and shearing of the thermoplastic extrusion process and still have the ability to absorb water (Souza et al., 2011). As PV values were higher than IV values, it is indicative that the use of hot water to disperse the extruded flour will favor an increase in water absorption. The coefficient of determination for PV was low $\left(\mathrm{r}^{2}=0.69\right)$ and the regression model was not significant. Using $3 \mathrm{~g}$ of flour in the RVA, a PV value of $415.3 \mathrm{cP}$ for raw bean flour and $140.0 \mathrm{cP}$ for extruded flour has been reported (Gomes et al., 2015), much lower values compared to the data in Table 5.

Table 5. Pasta propriety of extruded and raw CCF of the cultivar BRS Guariba.

\begin{tabular}{ccccccccc}
\hline Treatments & $\begin{array}{c}\mathbf{T} \\
\left({ }^{\mathbf{C}} \mathbf{C}\right.\end{array}$ & $\begin{array}{c}\mathbf{M} \\
\mathbf{( \% )}\end{array}$ & $\begin{array}{c}\mathbf{I V} \\
\mathbf{( c P )}\end{array}$ & $\begin{array}{c}\mathbf{P V} \\
\mathbf{( c P )}\end{array}$ & $\begin{array}{c}\mathbf{T R} \\
(\mathbf{c P})\end{array}$ & $\begin{array}{c}\mathbf{B D} \\
\mathbf{( c P )}\end{array}$ & $\begin{array}{c}\mathbf{F V} \\
(\mathbf{c P})\end{array}$ & $\begin{array}{c}\text { SB } \\
(\mathbf{c P})\end{array}$ \\
\hline 1 & 130 & 17 & $405.67 \mathrm{c}$ & $492.00 \mathrm{~b}$ & $162.00 \mathrm{~b}$ & $330.00 \mathrm{~b}$ & $458.00 \mathrm{~b}$ & $296.00 \mathrm{~b}$ \\
\hline 2 & 160 & 17 & $320.00 \mathrm{e}$ & $418.67 \mathrm{c}$ & $150.67 \mathrm{c}$ & $268.00 \mathrm{c}$ & $446.00 \mathrm{~b}$ & $295.33 \mathrm{~b}$ \\
\hline 3 & 130 & 21 & $319.00 \mathrm{e}$ & $365.00 \mathrm{~d}$ & $103.67 \mathrm{f}$ & $261.33 \mathrm{c}$ & $343.67 \mathrm{c}$ & $240.00 \mathrm{c}$ \\
\hline 4 & 160 & 21 & $354.00 \mathrm{~d}$ & $421.33 \mathrm{c}$ & $111.00 \mathrm{e}$ & $310.33 \mathrm{~b}$ & $356.67 \mathrm{c}$ & $245.67 \mathrm{c}$ \\
\hline 5 & 124 & 19 & $423.00 \mathrm{~b}$ & $616.67 \mathrm{a}$ & $214.00 \mathrm{a}$ & $402.67 \mathrm{a}$ & $547.33 \mathrm{a}$ & $333.33 \mathrm{a}$ \\
\hline 6 & 166 & 19 & $458.33 \mathrm{a}$ & $509.00 \mathrm{~b}$ & $111.67 \mathrm{e}$ & $397.33 \mathrm{a}$ & $334.67 \mathrm{c}$ & $223.00 \mathrm{c}$ \\
\hline 7 & 145 & 16.2 & $397.00 \mathrm{c}$ & $470.67 \mathrm{~b}$ & $149.00 \mathrm{c}$ & $321.67 \mathrm{~b}$ & $433.00 \mathrm{~b}$ & $284.00 \mathrm{~b}$ \\
\hline 8 & 145 & 21.8 & $346.00 \mathrm{~d}$ & $414.67 \mathrm{c}$ & $105.67 \mathrm{f}$ & $309.00 \mathrm{~b}$ & $344.33 \mathrm{~b}$ & $238.67 \mathrm{c}$ \\
\hline 9 & 145 & 19 & $317.00 \mathrm{e}$ & $378.67 \mathrm{~d}$ & $119.33 \mathrm{~d}$ & $259.33 \mathrm{c}$ & $363.67 \mathrm{c}$ & $244.33 \mathrm{c}$ \\
\hline 10 & 145 & 19 & $292.33 \mathrm{e}$ & $354.67 \mathrm{~d}$ & $110.33 \mathrm{e}$ & $244.33 \mathrm{c}$ & $344.67 \mathrm{c}$ & $234.33 \mathrm{c}$ \\
\hline 11 & 145 & 19 & $374.33 \mathrm{c}$ & $458.33 \mathrm{~b}$ & $156.00 \mathrm{~b}$ & $302.33 \mathrm{~b}$ & $441.33 \mathrm{~b}$ & $285.33 \mathrm{~b}$ \\
\hline 12 & 145 & 19 & $297.33 \mathrm{e}$ & $353.67 \mathrm{~d}$ & $104.67 \mathrm{f}$ & $249.00 \mathrm{c}$ & $330.00 \mathrm{c}$ & $225.33 \mathrm{c}$ \\
\hline & Raw flour & & 36.67 & 7245.00 & 4972.33 & 2272.67 & 9940.33 & 4968.00 \\
\hline
\end{tabular}

$\mathrm{IV}=$ Initial viscosity, $\mathrm{PV}=$ Peak viscosity, $\mathrm{TR}=$ Trough, $\mathrm{BD}=$ Breakdown, $\mathrm{FV}=$ Final viscosity; $\mathrm{SB}=$ Setback. Means followed by the same letter in the column do not differ statistically from each other by the Scott-Knott test at $5 \%$ probability.

TR values of all extruded CCF were almost 50 times lower than raw CCF. The highest value was obtained from the extruded CCF at the lowest temperature $\left(124^{\circ} \mathrm{C}\right)$ and intermediate moisture $\left(19^{\circ} \mathrm{C}\right)$, which was almost 2 times higher than the lowest observed value and differed significantly $(p<0.05)$ from the other 5 clusters (Table 5). The regression model for TR was predictive $\left(\mathrm{r}^{2}=0.79\right)$ and the significant model $(p<0.05)$ (Table 6$)$ is significantly and negatively affected by the linear effect of temperature (Figure 1), the moisture content did not influence significantly.

Table 6. Values of coefficients estimated by multiple linear regression for IV, PV, TR, BD, FV, and SB in CCF of cultivar BRS Guariba.

\begin{tabular}{ccccccc}
\hline Coefficients & IV & PV & TR & BD & FV & SB \\
\hline$\beta_{0}$ & $320.25^{*}$ & $386.33^{*}$ & $122.58^{*}$ & $263.75^{*}$ & 369.92 & 247.33 \\
\hline$\beta_{1}$ & $-12.65^{\mathrm{ns}}$ & $-34.58^{\mathrm{ns}}$ & $-30.34^{*}$ & $-4.24^{\mathrm{ns}}$ & $-63.05^{*}$ & $-32.71^{*}$ \\
\hline$\beta_{11}$ & $33.04^{\mathrm{ns}}$ & $68.62^{*}$ & $16.81^{\mathrm{ns}}$ & $51.81^{*}$ & $32.10^{\mathrm{ns}}$ & $15.29^{\mathrm{ns}}$ \\
\hline$\beta_{2}$ & $-15.35^{\mathrm{ns}}$ & $-12.02^{\mathrm{ns}}$ & $-8.16^{\mathrm{ns}}$ & $-3.86^{\mathrm{ns}}$ & $-15.55^{\mathrm{ns}}$ & $-7.39^{\mathrm{ns}}$ \\
\hline$\beta_{22}$ & $15.88^{\mathrm{ns}}$ & $8.54^{\mathrm{ns}}$ & $-0.94^{\mathrm{ns}}$ & $9.48^{\mathrm{ns}}$ & $5.94^{\mathrm{ns}}$ & $6.88^{\mathrm{ns}}$ \\
\hline$\beta_{12}$ & $30.17^{\mathrm{ns}}$ & $32.41^{\mathrm{ns}}$ & $4.66^{\mathrm{ns}}$ & $27.75^{\mathrm{ns}}$ & $6.25^{\mathrm{ns}}$ & $1.58^{\mathrm{ns}}$ \\
\hline
\end{tabular}


Table 6. Continued..

\begin{tabular}{|c|c|c|c|c|c|c|}
\hline Coefficients & IV & PV & TR & BD & FV & SB \\
\hline $\mathbf{r}^{2}$ & 0.66 & 0.69 & 0.79 & 0.66 & 0.79 & 0.79 \\
\hline F value & $1.92 \mathrm{~ns}$ & $2.68^{\mathrm{ns}}$ & $4.52 *$ & $2.31^{\mathrm{ns}}$ & $4.44 *$ & $4.21^{\mathrm{ns}}$ \\
\hline $\mathrm{p}$ & $0.225^{\mathrm{ns}}$ & $0.130^{\mathrm{ns}}$ & $0.047 *$ & $0.169^{\mathrm{ns}}$ & $0.048 *$ & $0.054^{\mathrm{ns}}$ \\
\hline Lack of fit & $0.316^{\mathrm{ns}}$ & $0.326^{\mathrm{ns}}$ & $0.635^{\mathrm{ns}}$ & $0.139^{\mathrm{ns}}$ & $0.717^{\mathrm{ns}}$ & $0.744^{\mathrm{ns}}$ \\
\hline
\end{tabular}

Low BD values and high stability rates are often associated with low hydration, low swelling force and high shear strength (Corke et al., 1997). By Scott-Knott analysis the extruded CCF from treatments 2, 3, 9, 10 and 12 showed no significant differences $(p<0.05)$ and the $\mathrm{BD}$ values were generally lower under intermediate processing conditions $\left(145{ }^{\circ} \mathrm{C}\right.$ and $19 \%$ moisture) yielding more stable pastes, while under extreme temperatures $\left(124\right.$ or $\left.166{ }^{\circ} \mathrm{C}\right)$ combined with intermediate moisture $(19 \%)$, the pastes were less stable. The BD values of the extruded CCF ranged from 244.33 to $402.67 \mathrm{cP}$, which were 5 to 9 times lower than the raw CCF. The coefficient of determination was low $\mathrm{r}^{2}=0.66$ ) and the regression model was not significant (Table 6 ).

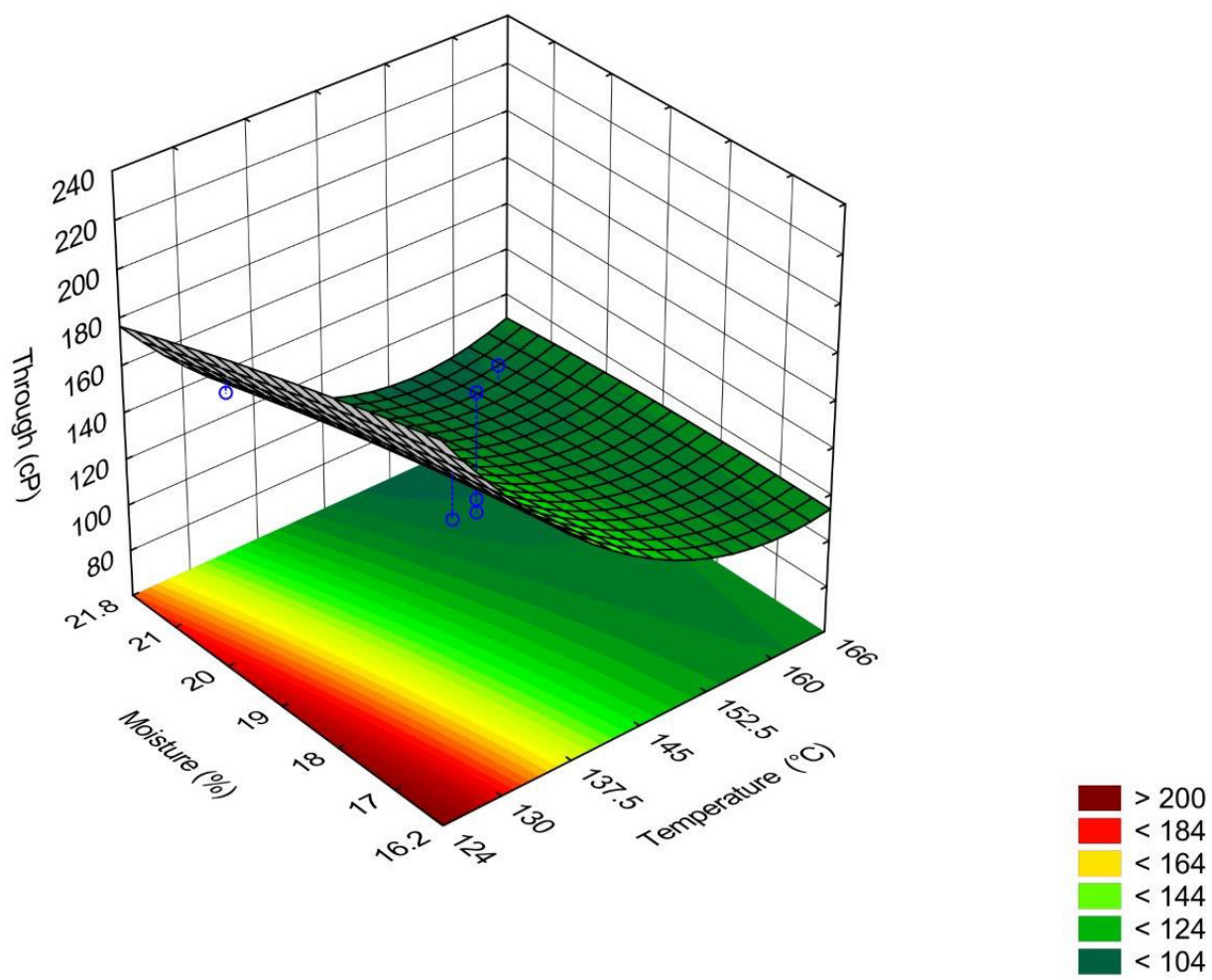

Figure 1. Effect of extrusion temperature $\left({ }^{\circ} \mathrm{C}\right)$ and flour moisture $(\%)$ of cowpea cotyledons on the trough value (TR).

All FV values were higher than TR, this increase in viscosity value at the end of the cooling cycle is due to the alignment of amylose chains and other interactions between proteins, lipids and complex carbohydrates (Kaur et al., 2007). The FV values ranged from $330.00 \mathrm{cP}$ to $547.33 \mathrm{cP}$, being 18 to 30 times lower than the final raw CCF viscosity (Table 5). In common bean raw flour has been reported an FV value of $885.7 \mathrm{cP}$, very low value, and $338.7 \mathrm{cP}$ for extruded flour (Gomes et al., 2015), which is close to those observed in Table 5. The highest values were obtained using the lowest $\left(124{ }^{\circ} \mathrm{C}\right)$ or highest $\left(166{ }^{\circ} \mathrm{C}\right)$ extrusion temperature combined with intermediate moisture $(19 \%)$ and the lowest values when intermediate values were used for the two independent variables $\left(145{ }^{\circ} \mathrm{C}\right.$ and $19 \%$ moisture) or when the value of one was 
maximum and another minimum, or in the opposite condition. By Scott-Knott analysis, 3 distinct clusters were formed $(p<0.05)$. The regression model for the FV was significant $(p<0.05)$ and the coefficient of determination was high $\left(\mathrm{r}^{2}=0.79\right)$ (Table 6$)$, being significantly and negatively influenced by the linear effect of temperature. In the graph of Figure 2, it is shown that the extrusion temperature increment decreased the $\mathrm{FV}$ value, the moisture content did not significantly influence this value, and this behavior was similar to TR.

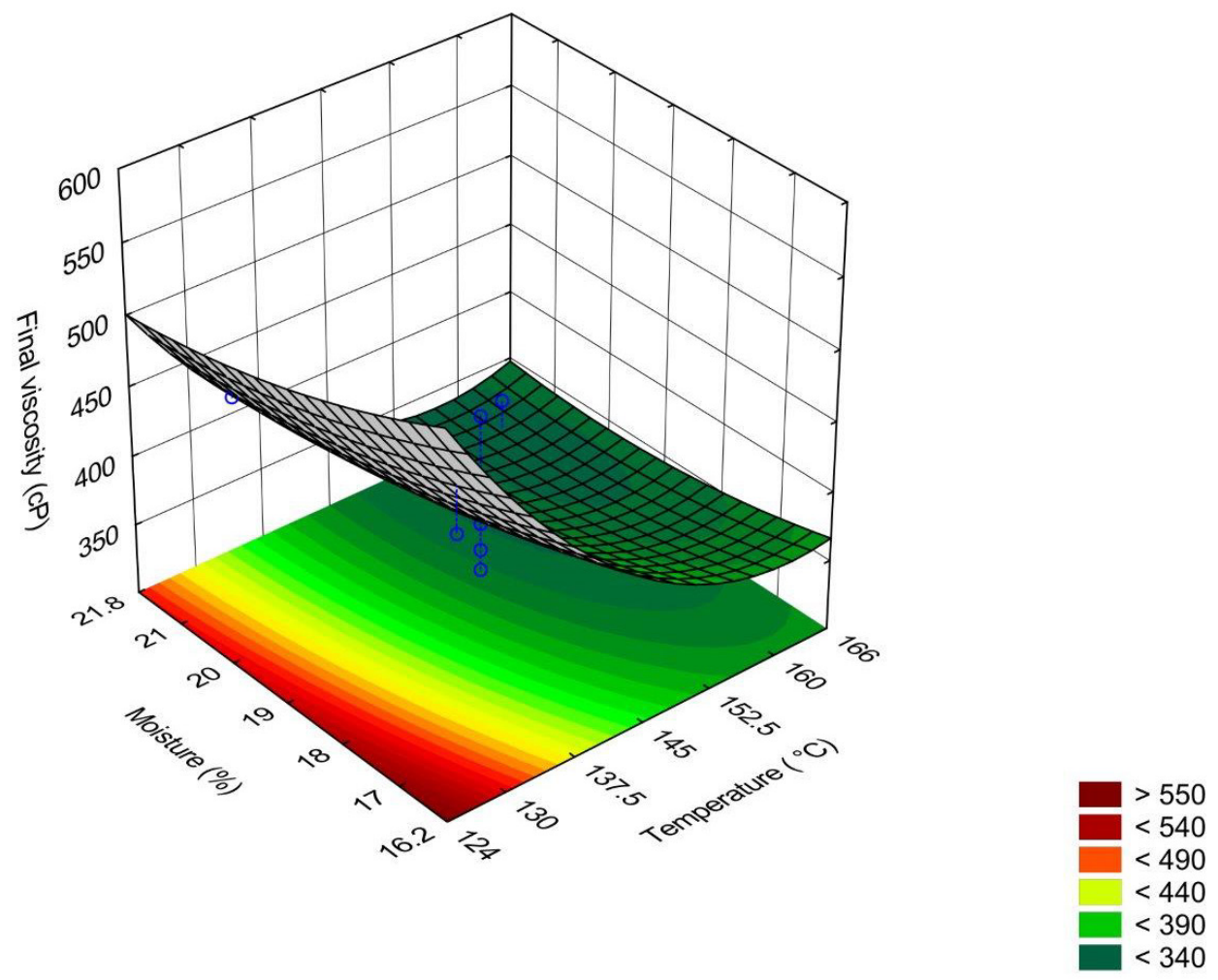

Figure 2. Effect of extrusion temperature $\left({ }^{\circ} \mathrm{C}\right)$ and flour moisture $(\%)$ of cowpea cotyledons on the final viscosity $(\mathrm{FV})$.

The SB values of extruded CCF were 15 to 22 times lower than raw $\mathrm{CCF}$, indicating a low retrograde rate. Among the extruded flours, these values ranged from $223.00 \mathrm{cP}$ to $333.33 \mathrm{cP}$, being distributed in 3 distinct groupings $(p<0.05)$ by the Scott-Knott test, being the highest value obtained for the extruded CCF at the lowest temperature $\left(124^{\circ} \mathrm{C}\right)$ and intermediate temperature $(19 \%)$, whose value differed statistically $(p<0.05)$ from the other extruded flours. The regression model for SB presented a high coefficient of determination $\left(r^{2}=0.79\right)$, but was not significant $(p=0.054)$ (Table 6).

\section{Conclusions}

The raw CCF of the two cultivars presented different pasta properties, except for the viscosity peak. The extrusion process drastically changed all viscosity parameters, resulting in CCF with high IV values and decreased values of other parameters. The extruded CCF presented distinct paste properties. The TR and FV values of the extruded flours were significantly influenced by the process temperature. Extruded CCF rapidly increased viscosity when dispersed in water at room temperature, and increased viscosity upon heating of water. The extruded CCF showed stability in maintaining viscosity and low tendency to retrograde, characteristics suitable for use as instant flour, with differential compared to traditional, because it has a higher value in protein content. 


\section{Acknowledgements}

The authors are grateful to the Brazilian Agricultural Research Corporation (EMBRAPA) for financial support, Process EMBRAPA Management System (SEG) No. 03.14.01.001.00.00.

\section{References}

Adebooye, O. C., \& Singh, V. (2008). Physico-chemical properties of the flours and starches of two varieties (Vigna unguiculata (L.) Walp.). Innovative Food Science \& Emerging Technologies, 9(1), 92-100. http://dx.doi.org/10.1016/j.ifset.2007.06.003

Adebowale, A. A., Sanni, L. O., \& Awonorin, S. O. (2005). Effect of texture modifiers on the physicochemical and sensory properties of dried Fufu. Food Science \& Technology International, 11(5), 373-382. http://dx.doi.org/10.1177/1082013205058531

Adegunwa, M. O., Bakare, H. A., Alamu, E. O., \& Abiodun, O. K. (2012). Processing effects on chemical, functional and pasting properties of cowpea flour from different varieties. Nigerian Food Journal, 30(1), 67-73. http://dx.doi.org/10.1016/S01897241(15)30015-1

Adenekan, M. K., Awonorin, S. O., Oguntoyinbo, S. I., Nupo, S. S., \& Odunmbaku, L. A. (2014). Functional properties and pasting characteristics of flour from five varieties of Nigerian pigeon pea (Cajanus cajan). Journal of Biological Sciences and Bioconservation, 6(1), 73-84

Arcaute, R. R., Rodrígues-Quijano, M., \& Carrillo, J. M. (2017). Starch viscosity measured with RVA as a tool for early selection of progenies for chip quality in a potato breeding program. Global Science Research Journals, 4(4), 373-382.

Ashogbon, A. O., \& Akintayo, E. T. (2013). Morphological and functional properties of starches from cereal and legume: a comparative study. International Journal of Food Sciences, 1(4), 72-83.

Association of Official Analytical Chemists - AOAC. (2012). Official Methods of Analysis of the Association of Official Analytical Chemists (19th ed.). Gaithersburg, Maryland: AOAC

Baranzelli, J., Kringel, D. H., Biduski, B., Zavareze, E. R., Miranda, M. Z., \& Dias, A. R. G. (2016, October). Efeitos da germinação natural e induzida nas propriedades de pasta de farinha de trigo. XXV Congresso Brasileiro de Ciência e Tecnologia de Alimentos. Gramado, RS: SBCTA, from http://www.ufrgs.br/sbctars-eventos/xxvcbcta/anais/files/1413.pdf

Barros Neto, B., Scarminio, I. S., \& Bruns, R. E. (2010). Como fazer experimentos: pesquisa e desenvolvimento na ciência e na indústria. (4 $4^{\mathrm{a}}$ ed.) Porto Alegre, RS: Bookman.

Boye, J., Zare, F., \& Pletch, A. (2010). Pulse proteins: Processing, characterization, functional properties and applications in food and feed. Food Research International, 43(2), 414-431. http://dx.doi.org/10.1016/j.foodres.2009.09.003

Brennan, M. A., Derbyshire, E., Tiwari, B. K., \& Brennan, C. S. (2013). Ready-to-eat snack products: The role of extrusion technology in developing consumer acceptable and nutritious snacks. International Journal of Food Science \& Technology, 48(5), 893-902. http://dx.doi.org/10.1111/ijfs. 12055

Camargo, C. M., Talhamento, A., Silva, R. S., Santos, R. F., Paraginski, R. T., \& Oliveira, M. (2014, October). Efeitos da temperatura de armazenamento na qualidade industrial de grãos de milho. VI Conferência Brasileira de Pós-Colheita, Maringá PR. from http://eventos.abrapos.org.br/anais/paperfile/110_20142111_01-29-49_4464.pdf

Corke, H., Wu, H., Yue, S., \& Sun, H. (1997). Developing Specialty Starches from New Crops: A Case Study Using Grain Amaranth. In G. M. Campbell, C. Webb, \& S. L. McKee (Eds.), Cereals: Novel Uses and Processes (95-100). New York: Plenum Press. http://dx.doi.org/10.1007/978-1-4757-2675-6_12.

Empresa Brasileira de Pesquisa Agropecuária (2019, August 9). Dados conjunturais da produção de feijão-comum (Phaseolus vulgaris L.) e caupi (Vigna unguiculata (L.) Walp.) no Brasil (1985 a 2017): área, produção e rendimento. Santo Antônio de Goiás: Embrapa Arroz e Feijão. Retrieved in 2020, Feb 26, from: http://www.cnpaf.embrapa.br/socioeconomia/index.htm

Fernandez, M. L., \& Berry, J. W. (1989). Rheological properties of flours and sensory characteristics of bread made from germinated chickpea. International Journal of Food Science \& Technology, 24(1), 103-110. http://dx.doi.org/10.1111/j.13652621.1989.tb00623.x

Food and Agriculture Organization of the United Nations (2019, October 22). FAOSTAT database. Retrieved in 2020, Feb 26, from http: www.fao.org/faostat/en/\#data/QC/visualize.

Fox, G., Visser, J., Skov, T., Meijering, I., \& Manley, M. (2014). Effect of different analysis conditions on Rapid Visco Analyser malt viscograms in relation to malt of varying fermentability. Journal of the Institute of Brewing, 120(3), 183-192. http://dx.doi.org/10.1002/jib.137

Gomes, G. M., Reis, R. C., \& Silva, C. A. D. T. (2012). Obtenção de farinha de feijão-caupi (Vigna unguiculata L. Walp.) Revista Brasileira de Produtos Agroindustriais, 14(1), 31-36. http://dx.doi.org/10.15871/1517-8595/rbpa.v14n1p31-36

Gomes, L. O. F., Santiago, R. A. C., Carvalho, A. V., Carvalho, R. N., Oliveira, I. G., \& Bassinello, P. Z. (2015). Application of extrude broken bean flour for formulation of gluten-free cake blends. Food Science and Technology, 35(2), 307-313. http://dx.doi.org/10.1590/1678-457X.6521

Han, X., \& Hamaker, B. R. (2001). Amylopectin fine structure and rice starch paste breakdown. Journal of Cereal Science, 34(3), 279-284. http://dx.doi.org/10.1006/jcrs.2001.0374 
Henshaw, F. O., McWatters, K. H., Oguntunde, A. O., \& Phillips, R. D. (1996). Pasting properties of cowpea flour: effects of soaking and decortication method. Journal of Agricultural and Food Chemistry, 44(7), 1864-1870. http://dx.doi.org/10.1021/jf950698d

Huang, J., Schols, H. A., Jin, Z., Sulmann, E., \& Voragen, A. G. J. (2007). Characterization of differently sized granule fractions of yellow pea, cowpea and chickpea starches after modification with acetic anhydride and vinyl acetate. Carbohydrate Polymers, 67(1), 11-20. http://dx.doi.org/10.1016/j.carbpol.2006.04.011

International Association for Cereal Science and Technology. (1996). Rapid Pasting Method using the Newport Rapid Visco Analyser (Standard Method 162, pp. 123-456). Vienna: ICC.

Kaur, A., Singh, N., Ezekiel, R., \& Guraya, H. S. (2007). Physicochemical, Thermal and pasting properties of starches separated from different potato cultivars grown at different locations. Food Chemistry, 101(2), 643-651.

http://dx.doi.org/10.1016/j.foodchem.2006.01.054

Kesarwari, A., Chiang, P. Y., \& Chen, S. S. (2016). Rapid Visco Analyzer measurements of japonica rice cultivars to study interrelationship between pasting properties and farming system. International Journal of Agronomy, 2016, e3595326. http://dx.doi.org/10.1155/2016/3595326

Malomo, O., Apo, R., \& Alamu, E. A. (2017). Development of spiced instant "moinmoin" produced from precooked cowpea flour using maize starch as binder. International Journal of Food Science and Nutrition Engineering, 7(4), 75-90.

Menegassi, B., Leonel, M., Mischan, M. M., \& Pinho, S. Z. (2007). Efeito de parâmetros de extrusão na cor e propriedade de pasta da farinha de mandioquinha-salsa (Arracacia xanthorrhiza). Ciência e Agrotecnologia, 31(6), 1780-1792. http://dx.doi.org/10.1590/S1413-70542007000600027

Michiyo, W., Tomoko, M., Kikuchi, T., Hiroshi, K., \& Naofumi, M. (2004). Application of pre-germinated brown rice for breadmaking. Cereal Chemistry, 81(4), 450-455. http://dx.doi.org/10.1094/CCHEM.2004.81.4.450

Núcleo de Estudos e Pesquisas em Alimentação - NEPA. (2011). Tabela Brasileira de Composição de Alimentos. (4th ed.). Campinas: UNICAMP.

Olapade, A. A., Ozumba, A. U., Solomon, H. M., Olatunji, O., \& Adelaja, S. O. (2005). Rheological Properties and Consumer Acceptance of "Moin-moin" Premix. Nigerian Food Journal, 23(1), 144-147.

Olkku, T., \& Rha, C. (1978). Gelatinisation of Starch and Wheat flour starch - A review. Food Chemistry, 3(4), $293-317$. http://dx.doi.org/10.1016/0308-8146(78)90037-7

Ortiz, M. E. R., Martín-Martínez, E. S., \& Padilla, L. P. M. (2008). Rheological and thermal properties of extrude mixtures of rice starch and isolated soy protein. Stach/Stärk, 60(10), 577-587.

Sandhu, K. S., Singh, N., \& Malhi, N. (2007). Some properties of corn grains and their flours I: Physicochemical, functional and chapati-making properties of flours. Food Chemistry, 101(3), 938-946. http://dx.doi.org/10.1016/j.foodchem.2006.02.040

Shimelis, E. A., Meaza, M., \& Rakshit, S. K. (2006). Physico-chemical properties, pasting behavior and functional characteristics of flours and starches from improved bean (Phaseolus vulgaris L.) varieties grown in East Africa. Agricultural Engineering International, 8, 1-19.

Souza, V. F., Ortiz, J. A. R., Nascimento, E. M. G. C., \& Ascheri, J. L. R. (2011). Pasting properties of expanded extrudate and pellets from corn flour and rice flour. Brazilian Journal of Food Technology, 14(2), 106-114. http://dx.doi.org/10.4260/BJFT2011140200014

Wani, I. A., Sogi, D. S., \& Gill, B. S. (2012). Physicochemical properties of acetylated starches from some Indian kidney bean (Phaseolus vulgaris L.) cultivars. International Journal of Food Science \& Technology, 47(9), 1993-1999. http://dx.doi.org/10.1111/j.1365-2621.2012.03062.x

Ye, J., Hu, X., Luo, S., Liu, W., Chen, J., Zeng, Z., \& Liu, C. (2018). Properties of starch after extrusion: a review. Stärke, 70(11/12), 1-8. http://dx.doi.org/10.1002/star.201700110

Zaidul, I., Norulaini, N., Omar, A., Yamauchi, H., \& Noda, T. (2007). RVA analysis of mixtures of wheat flour and potato, sweet potato, yam and cassava starches. Carbohydrate Polymers, 69(4), 784-791. http://dx.doi.org/10.1016/j.carbpol.2007.02.021

Funding: Brazilian Agricultural Research Corporation (EMBRAPA) - Process EMBRAPA Management System (SEG) No. 03.14.01.001.00.00; National Council for Scientific Development and Technological (CNPq) -CNPq-Brasil No. 313750/2019-0 for the scholarship. 